$\xi=-1$

\title{
Crude Oil Effect on the Clayey Soil Mechanical and Physical Properties
}

\author{
Rana A. J. Al-Adhamii ${ }^{1 *}$, Mohammed Y. Fattah², Maysam Th. Al-Hadidi ${ }^{3}$ \\ ${ }^{l}$ Civil Engineering Department, Dijlah University College \\ ${ }^{2}$ Civil Engineering Department, University of Technology \\ ${ }^{3}$ Water Resources Engineering Department, Baghdad University \\ *Corresponding author E-mail: rana.alhdeede@duc.edu.iq
}

\begin{abstract}
Soil defilement with "raw petroleum" is a standout amongst the most across the board and genuine ecological issues going up against both the industrialized and oil country like Iraq. Along these lines, the impact of "raw petroleum" on soil contamination is one of most critical subjects that review these days. The present examination expects to research "unrefined oil"effectson the mechanical and physical properties of clayey soils. The dirt examples were acquired from Al-Doura area in Baghdad city and arranged by the "Brought together Soil Grouping Framework (USCS)" as silty mud of low pliancy (CL). Research center tests were done on contaminated and unpolluted soil tests with same thickness. The dirtied tests are set up by blending the dirts with various percent of "raw petroleum", and these percent are $5 \%, 10 \%$ and $15 \%$ by dry weight. The exploration results demonstrate a reduction in the quality of the dirt, explicit gravity, greatest dry thickness and ideal dampness content. Then again, the outcomes showed an expansion in Atterberg cutoff points and compressibility of the dirt. The outcomes demonstrated additionally an impressive increment in the estimation of combination parameters such ascoefficient of volume compressibility, pressure file and lessening in the coefficient of solidification and shear quality.
\end{abstract}

Keywords: Crude oil; Clayey Soil; Contamination; Mechanical Properties; Consolidation; Shear Strength.

\section{Introduction}

The great development that happens in the field of industry was companied with the sources of pollution of the environment. Where with the increasing of the number of petrochemicals factories and the pollution that caused to environment. Beside the groundwater pollution, the soil is also affected by "the oilspills" and "pipelines" or"tanks leakage". In spite of that, there are a lot of researches on the subject but the exact effect of the pollution on the properties of the clayey soil has been not found yet (Kermani and Ebadi, 2012).

The most widely recognized soil dirtying material is "raw petroleum", where everywhere throughout the world consistently over than "two million tons" of oil are created and at least "10 percent" discover its way to the encompassing from "pipeline break", "spillage from tanks", "tanker mishaps", "release fromcoastal offices" close to "seaward oil preparations" (Abousinina et al., 2015) The spread of contamination is relying upon the properties of the dirtied zone (soils) and synthetic organization of the contaminant itself (Fine et al., 1997). Also,it is tied with the filtration works and any likely authorization of contaminated soils. So it is required to watch the properties of the dirt and its attitude with the contaminated material. That data is vital when oil spilled from oil tank and preparing plants is occur and cause contamination in the encompassing soils. Along these lines, it is important to establish the impact of oil contamination on the current structures.

In 2012, Kermani and Ebadihave showed that "the treatment strategies are exorbitant, the use of tainted soil in development as a street base, surfacing material, a refill or other building applications, for example, landfill tops, appears to be efficient. It must be noticed that moving sullied soil to different zones could impactsly affect human wellbeing and the earth".

There are a few treatment strategies for "oil-contaminated"soils. One of these techniques is utilizing that sullied soil as clearing material.

In 1994, Meegoda and Ratnaweera have beenchecked the compressibility of contaminated fine-grained soils by union tests. They checked two clayey soils (low versatility and high pliancy). They utilized "glycerol and propanol synthetics" and they found an expansion in the compressibility,also redress factors were proposed to evaluate the adjustment in the pressure record.

Ali (1999) examined the impacts of kerosenecontamination on some geotechnical properties of soil. The aftereffects of testing demonstrate that the defilement of soil by oil impacts on physical properties and additionally a mechanical properties with in oil content. The aftereffects of compaction tests demonstrated those tainted examples not exactly of uncontaminated.

In 2007, Khamehchiyan et al. have examined the properties of two soils (earth and sand) these two soils contaminated by raw petroleum. The consequences of the investigation demonstrated decrease in the shear quality, most extreme dry thickness, ideal moisturecontent andAtterberg's breaking points with expanding of raw petroleum in the dirt.

In 2012, Kermaniand Ebadi directed tests to discover the impact of "raw petroleum" contamination on a few properties of finegrained soils."The results demonstrated that an expansion in the edge of inner contact, greatest dry thickness, pressure list, and 
Atterberg confines and in addition a decline in ideal water substance and attachment happen as the oil content increments. Additionally, maturing caused a further lessening in attachment yet had no explicit impact on the inside erosion edge".

Karkush and Abdul Kareem (2017) has examined the impact of "fuel oil" on the properties of soil, it was shown that the "fuel oil" has negative impact on the properties of soil.

Iraq is one of the principle nations creating and sending out oil and gas. In that capacity, huge regions of its desert were sullied with unrefined petroleum. This examination is led as an endeavor to decide the impacts of raw petroleum tainting on the imperative mechanical properties of clayey soil, which is the first of its sort around there. The consequences of this investigation will fill in as benchmark data to decide the potential use of oil tainted mud for building and development.

\section{The Materials and the studying method}

\subsection{Properties of the soil}

A brown clayey soil was brought up from Al-Doura district in Baghdad city / Iraq. A trial pit was excavated using mechanical shovel to a depth of $2 \mathrm{~m}$ below the N.G.L. Standard tests were performed to determine the physical properties of the soil. The physical properties of the soil are shown in Table 1 and the particle size distribution is shown in Figure 1.

Table 1:The physical properties of the soil.

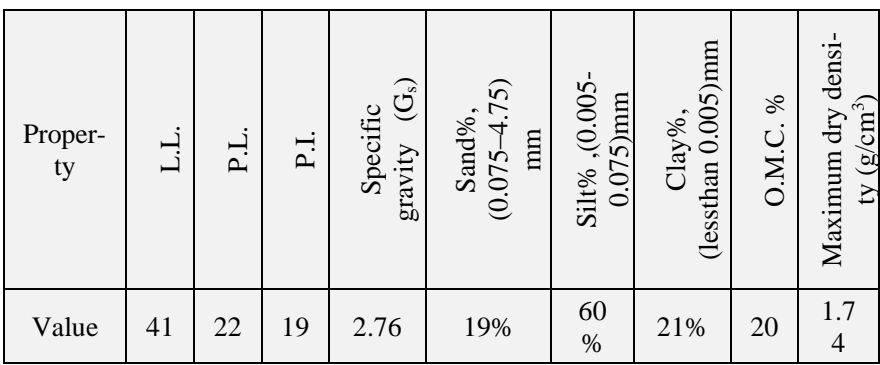

Depending on the "Unified Soil Classification System (USCS)", the soil is classified as low plasticity clay (CL).

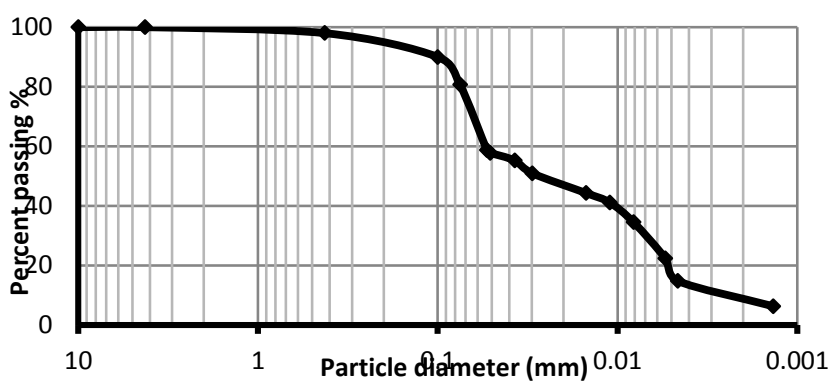

Fig.1: Particle size distribution of the natural soil.

\subsection{Crude oil properties}

The agent used in this study was crude oil. This product was brought up from Al-Doura refinery in Baghdad. The physical properties tests were conducted by the Ministry of Oil. The results are shown in Table 2 . This product was chosen in this study because it is the product stored in Al-Doura refinery in Baghdad.

Table 2: Crude oil properties (strategy line- Basra).

\begin{tabular}{|c|c|c|c|c|c|c|}
\hline $\begin{array}{c}\text { Index } \\
\text { proper- } \\
\text { ty }\end{array}$ & $\begin{array}{c}\text { Viscosi- } \\
\text { ty } \\
\text { @21.1 } \\
\mathrm{C}\end{array}$ & $\begin{array}{c}\text { Densi- } \\
\text { ty } \\
@ 15 \\
{ }^{\circ} \mathrm{C}\end{array}$ & $\begin{array}{c}\text { API } \\
\text { gravity } \\
@ 15.6^{\circ} \\
\text { C }\end{array}$ & $\begin{array}{l}\text { R.V.P } \\
\mathrm{Kg} / \mathrm{cm}\end{array}$ & $\begin{array}{c}\text { Specific } \\
\text { gravi- } \\
\text { ty@ } \\
15.6^{\circ} \mathrm{C}\end{array}$ & $\begin{array}{c}\text { Total } \\
\text { Dis- } \\
\text { til. } \\
\text { Vol. } \\
\%\end{array}$ \\
\hline Value & 15.0 & 0.8676 & 31.5 & 0.52 & 0.8681 & 47.0 \\
\hline
\end{tabular}

\section{Preparation of Specimens for Routine Tests and Testing}

The soil sample was air dried and crushed so as to pass through sieve No. (10). After drying, the soil was divided into four portions.

The crude oil was used in this study to represent one of the hydrocarbon components. In this study, three percentages of crude oil are used $(5,10$ and $15 \%)$, each percent was mixed thoroughly with the soil sample by weight to the dry weight of the soil. After the soil samples were prepared by mixing them with appropriate water content and crude oil content, the samples were preserved into plastic cans for 3 days to get a homogeneous blend. The soil samples were compacted according to "standard Proctor test (ASTM D698)", and each one was compacted at its "maximum dry density (MDD)" and "optimum moisture content (OMC)". "Consolidation, unconfinedcompression, and direct shear tests" were performed on these samples. The procedures for conducting these tests were in accordance with "standard specifications of ASTM".

\section{Results and Discussion}

\subsection{The specific gravity:}

The specific gravity of all uncontaminated and contaminated soil samples was determined according to ASTM D854-58. Figure 2 illustratesresults of the specific gravity tests of soil samples that were mixed with different percent of crude oil. The figure shows decrease of specific gravity values of polluted soil with the increase of crude oil content as a result of increasing lightweight materials of the same volume because of the low density of the crude oil.

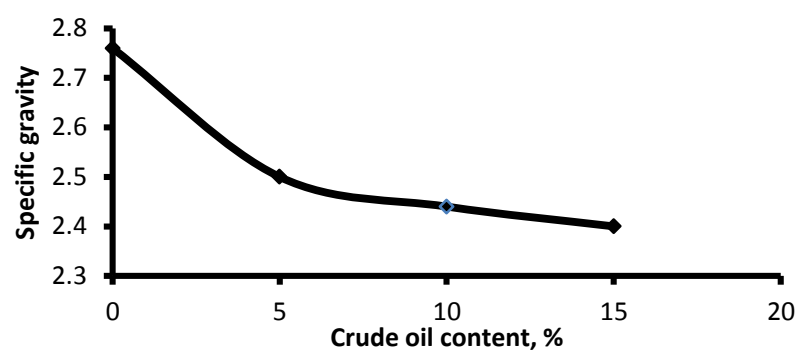

Fig. 2: The effect of oil content on the specific gravity of the clayey soil

\subsection{Grain size distribution}

Grain size distribution has been tested in accordance with ASTM D421-58 and D422-63. Figure 3 shows the grain size distributions before and after contamination with $5 \%, 10 \%$ and $15 \%$ by weight of crude oil. From the figure, it is noticed that there is a change in gradation of particles with the increase in percent of crude oil added, whereas $\mathrm{D}_{30}$ varied from $(0.006)$ to $(0.032)$ with increasing crude oil content from 0 to $15 \%$, that means thesoil becomes coarser with the increase of crude oil.

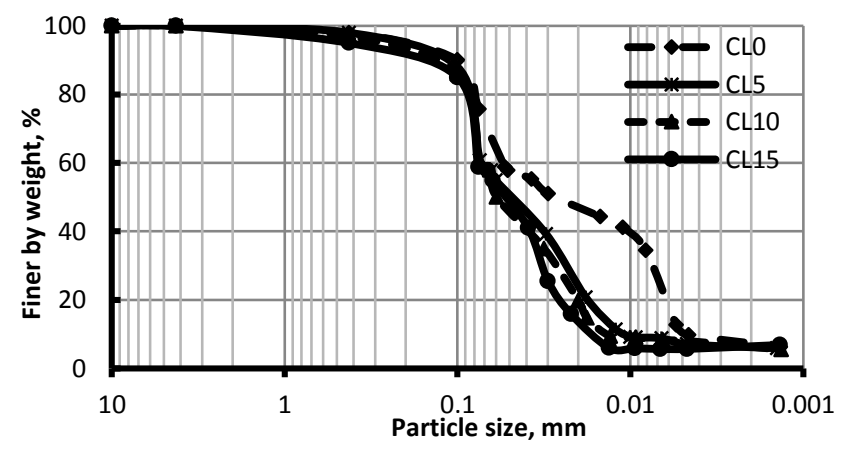

Fig. 3: Grain size distribution before and after contamination. 


\subsection{Atterberg limits}

As it is known, as far as possible are determined by "plastic cutoff points" and "fluid breaking points "and "versatility file" and with the end goal to research the impact of "unrefined petroleum" contamination on the clayey soil, Atterberg limit tests were done by "Casagrande technique". The assessed Atterberg limits were not exactly the normal in light of the high measure of residue and fine sand. As far as possible, fluid limit and pliancy file are tried forun contaminated and pollutedsoil with 5,10 and $15 \%$ by weight of dry soil with various measures of contamination. The outcomes are appeared in Figure 4. The outcomes demonstrate an expansion in as far as possible, plastic limit and versatility record with expanding of the unrefined petroleum content.

In 1994, Das showed the accompanying reality "twofold layer water can be characterized as the water could hold to the mud particles by the at-footing powers. Most the internal layer of the twofold layer water, which is unequivocally held by the mud molecule, is known as (adsorbed water). This conduct of water around the earth particles gives clayey soils their plastic properties, the water in the voids of the dirt that isn't consumed by the mud particles and that effectively moves in the dirt is called (free water). The free water decides the fluid conduct of the dirt". The diminishing in the measure of thediffused water layer encourages nearer contact between the dirt particles bringing about flocculation/agglomeration of these particles (Alrubaye et al., 2016).

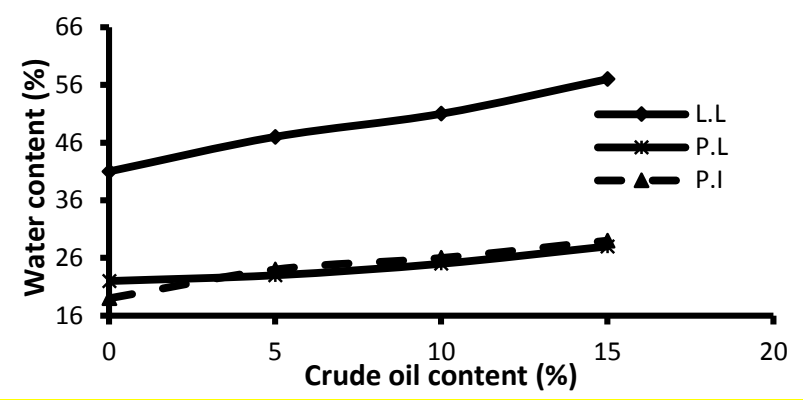

Fig. 4: Effect of oil content on the Atterberg limits.

Since unrefined petroleum covers earth particles and does not allow water atoms to achieve the twofold layer water, more water is required for the dirt to acquire plastic properties. This may be the explanation behind the expansion in plastic limit. In any case, if the oil situates the soilparticles, the majority of the water added to the dirt amid the test will join the free water layer in light of the fact that the stream attributes of mud rely upon free water.

At last, if a large portion of the additional water achieves the free water and not the twofold layer water, the little contrast among LL and PL, and therefore the little PI, would appear to be sensible.

These outcomes are in concurrence with those of Ur-Rehman et al. (2007) and conversely withthat have found byKhamehchiyan et al. (2007) who have expressed that as far as possible are diminishing when raw petroleum pollution increment in CL tests.

The dirt is delegated earth but since the PI increments in a little esteem, the conduct becomesmore like silty soils than that of muds. In 2012, Kermani and Ebadishowed that "thecontaminated soil can be utilized as fine-grained totals (fillers)for black-top or cement blends. Despite the fact that by utilization of the dirt in such blends we may control the engendering of pollution, the impact of expansion of contam-inated soil to the blend on obstruction parameters must be examined".

\subsection{The compaction test "Dampness thickness relation- ship"}

The compaction tests were finished by ASTM (D-698). The consequences of these tests demonstrated that with expanding unre- fined petroleum from 0 to $15 \%$, the "greatest dry thickness" diminished from 1.74 to $1.65 \mathrm{~g} / \mathrm{cm} 3$, and the "ideal water content" diminishes from 19.2 to $15 \%$ as indicated Figure 5.

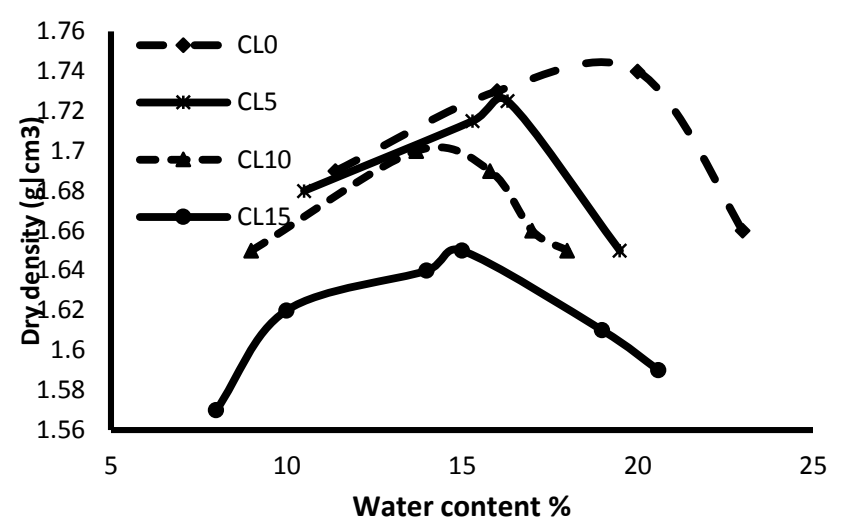

Fig. 5: Relationship between the dry density and water content for uncontaminated and contaminated clayey soil for different crude oil contents.

Figures 6 and 7 are demonstrating the impact of unrefined petroleum on the "maxi-mum dry thickness" and "ideal dampness content", individually. From these figures, one can take note of that the water content required to reach the"maximum dry thickness" has diminished from $20 \%$ to $15 \%$ and the "greatest dry thickness" diminished from $1.74 \mathrm{~g} / \mathrm{cm} 3$ to $1.65 \mathrm{~g} / \mathrm{cm} 3$ as unrefined petroleum content expanded to $15 \%$ by dry weight of pol-luted soil. This might be expected to thefact that "the oil has in part possessed the between particles voids and the event of oil has changed the dirt to a condition of losing material then an unpolluted soil". Along these lines, with expanding the contaminated material, the style of the compaction bends changing over from a conventional style for unpolluted soil to ill defined style for dirtied soils.

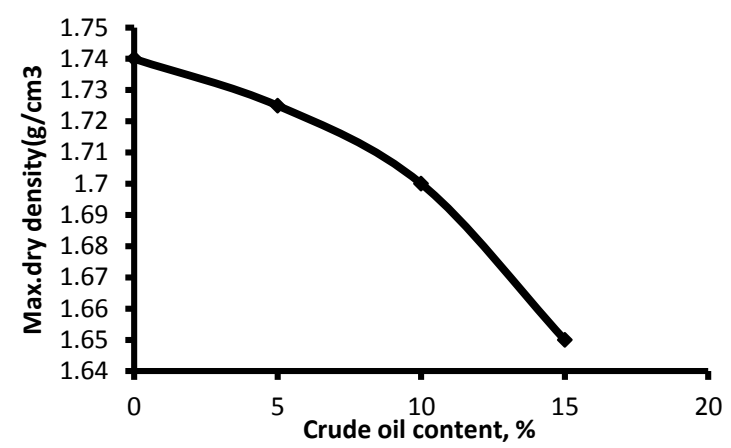

Fig. 6: Relationship between crude oil content and maximum dry unit weight.

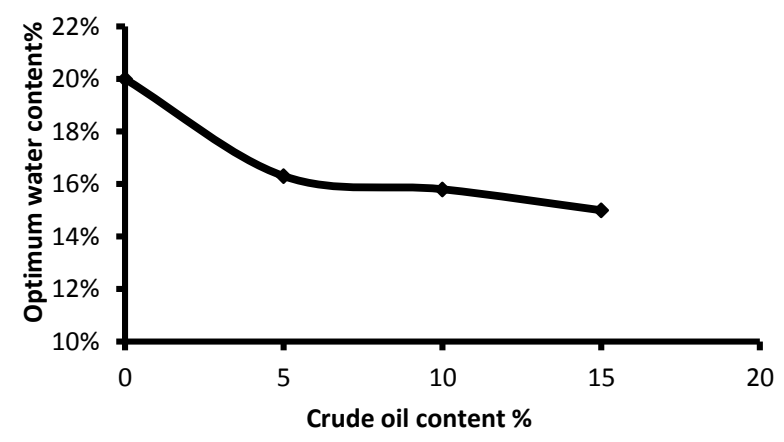

Fig. 7: Relationship between crude oil content and the O.M.C.

\subsection{The Effect of the crude oil on the mechanical prop- erties of the soil:}

In this paper, the consolidation behavior of unpolluted and polluted soils was found by "one dimensional consolidation test". After 
compacting the samples at "the maximum dry density MDD"and "optimum moisture content OMC" of the standard Proctor test, All the samples were then soaked in water. The results of consolidation tests are presented as void ratio versus effective consolidation stress and void-ratio versus logarithm of effective consolidation stress are illustrated in Figures 8 and 9, respectively for all the tested samples.

The difference in void ratio increases with the increase in crude oil content as shown in Figures 8 and 9. It is noticed during the test that the crude oil expelled and the percent of expel increased with increasing crude oil content so that the increase in thedifference in void ratio may be attributed to this reason. From Figures 8 and 9 , the values of void ratio, compression index, swelling index, coefficient of volume change and coefficient of compressibility of soil tests can be determined and are tabulated in Table (3).

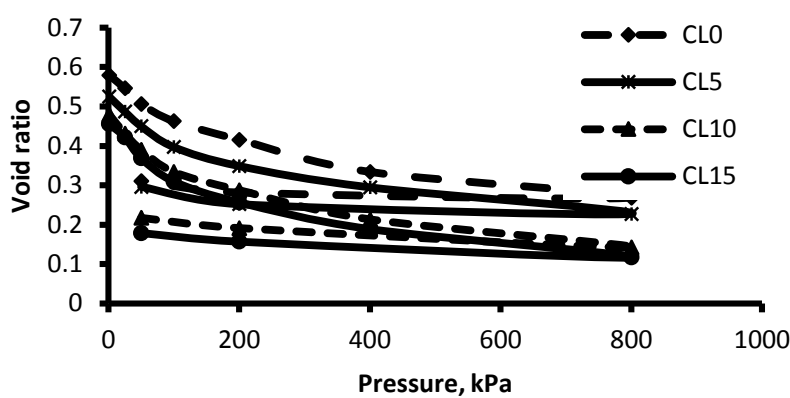

Fig. 8: Void ratio-pressure curve for clean and contaminated clayey soil.

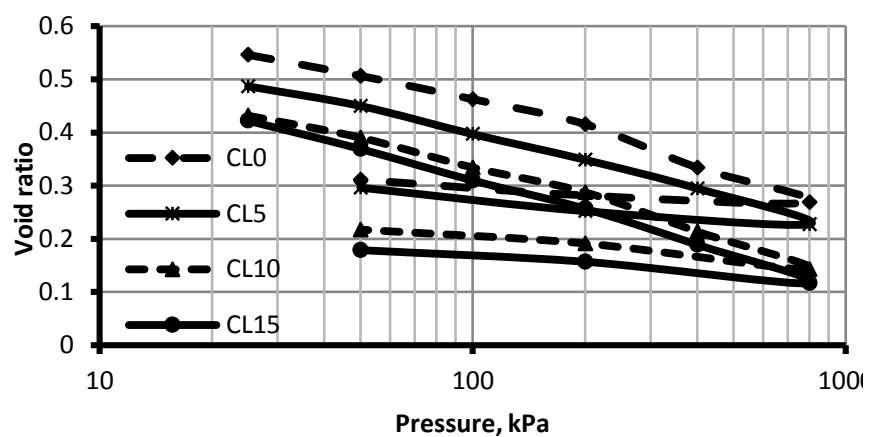

Fig. 9: Void ratio-pressure curve for clean and contaminated clayey soil.

Table 3: Results of consolidation test

\begin{tabular}{|l|c|c|c|c|}
\hline \multicolumn{1}{|c|}{ Coeff.ICrudeoil } & CL0 & CL5 & CL10 & CL15 \\
\hline $\begin{array}{l}\text { Coefficientofcompressi- } \\
\text { bility }\left(\mathbf{a}_{\mathbf{v}}\right)\left(\mathbf{m}^{\mathbf{2}} / \mathbf{k N}\right)\end{array}$ & $\begin{array}{c}0.00080 \\
7\end{array}$ & $\begin{array}{c}0.00082 \\
8\end{array}$ & $\begin{array}{c}0.000949 \\
3\end{array}$ & 0.00095 \\
\hline $\begin{array}{l}\text { Coefficientof volume } \\
\text { change }\left(\mathbf{m}_{\mathbf{v}}\right)\end{array}$ & $\begin{array}{c}0.00051 \\
\mathbf{2} / \mathbf{k N})\end{array}$ & $\begin{array}{c}0.00054 \\
3\end{array}$ & 0.000641 & $\begin{array}{c}0.00065 \\
2\end{array}$ \\
\hline Compression index $\left(\mathbf{C}_{\mathbf{c}}\right)$ & 0.2162 & 0.223 & 0.236 & 0.2394 \\
\hline Swelling Index $\left(\mathbf{C}_{\mathbf{e}}\right)$ & 0.02125 & 0.04053 & 0.08112 & 0.06675 \\
\hline Initial void ratio $\left(\mathbf{e}_{\mathbf{0}}\right)$ & 0.5796 & 0.525 & 0.48 & 0.456 \\
\hline Final void ratio $\left(\mathbf{e}_{\mathbf{f}}\right)$ & $\begin{array}{c}0.31106 \\
8\end{array}$ & 0.29625 & 0.2173 & 0.1788 \\
\hline
\end{tabular}

It can be inferred from the figures and Table 3 that the pollution by crude oil is affecting the compressibility of the soil, where it is tending to reduce it with increasing that polluted material. Meegoda and Ratnaweera (1994) and Ur-Rehman et al. (2007)reached to that end likewise and they clarified as"this happens as a result of the oil impacts of the oil which lessen the contact between the dirt particles. Furthermore, being covered with oil and the decrease in the Explicit Surface Territory (SSA) makes mud particles can't assimilate water effortlessly. In this manner, surrendered water particles don't will in general return to the surface of dirt minerals so playing out a pre-combination before common structures are worked over the defiled soil will altogether diminish the porosity of the dirt and enhance its properties" (Kermani and Ebadi, 2012). The pressure record somewhat increments with expanding raw petroleum content. The expansion in pressure file can be credited to the nearness of natural issue in the raw petroleum. "The compressibility of an earth soil is subject to the estimation of Cc; big- ger estimation of $\mathrm{Cc}$ will prompt higher compressibility". The estimations of $\mathrm{Cc}$ are appeared in Figure 10.

In 1998, Ismaael and Mollah studied the leached sand and they showed that the compression index and swelling index increased and for polluted clayey soil, there was extra settlement than predictable when a new structure loading is subjected to the soil. This increase may reach to almost double the dominated value.

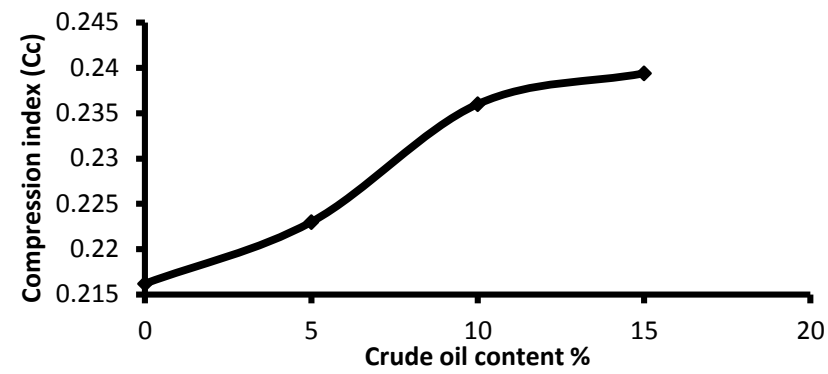

Figure 10: Relationship between $\mathrm{Cc}$ and crude oil content for the clayey soil.

Figures 11 to 13 show the variation of the coefficient of consolidation with respect to crude oil content for the samples that were compacted at MDD and OMC of the standard Proctor test under pressures of 25,100 and $800 \mathrm{kPa}$, respectively.

It can be noticed from the figures that the coefficient of consolidation increases with increasing of crude oil content at low stress range $(25 \mathrm{kPa})$ which is almost about the pre-consolidation stress and that will lead to the increase of the coefficient of the permeability $\mathrm{k}$ that is estimated indirectly from the relation:

$$
\mathbf{k}=\mathbf{m}_{\mathbf{v}} \times \mathbf{C}_{\mathbf{v}} \times \square_{\mathbf{w}}
$$

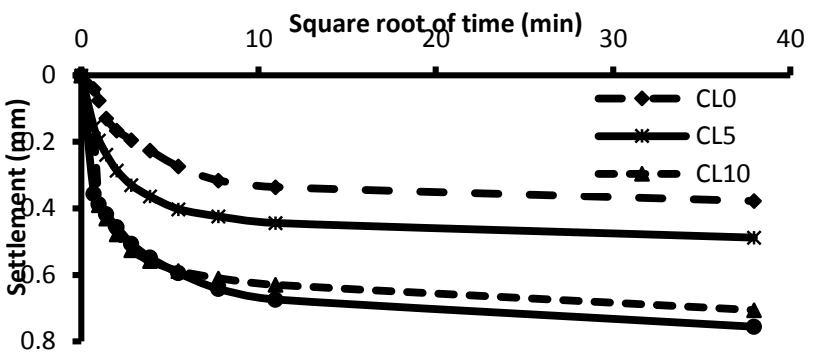

Fig. 11: Relationship between settlement and square root of time of the uncontaminated and contaminated soil at a pressure $25 \mathrm{kPa}$.

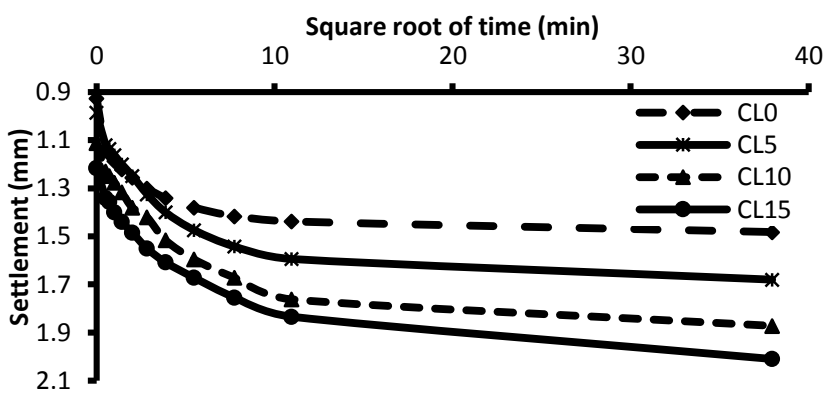

Fig. 12: Relationship between settlement and the square root of time of theuncontaminated and contaminated soil at a pressure of $100 \mathrm{kPa}$.

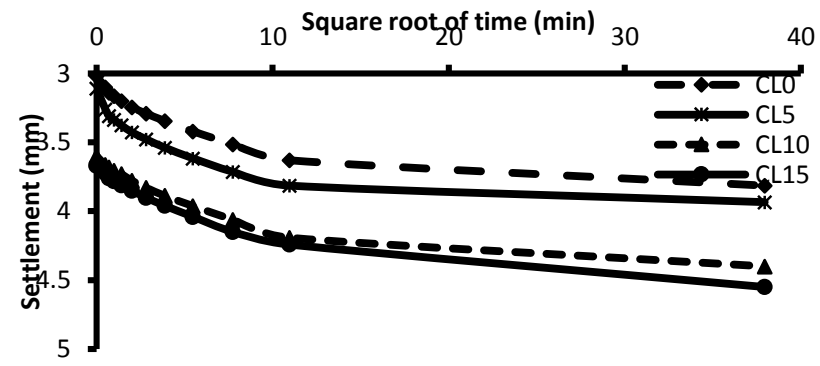

Fig. 13: Relationship between settlement and the square root of time of the uncontaminated and contaminated soil at a pressure of $800 \mathrm{kPa}$ 
Table (4) illustrates the values of $\mathrm{C}_{\mathrm{v}}$ and $\mathrm{k}$ for uncontaminated and contaminated soil with $(5,10,15) \%$ crude oil at stress $25 \mathrm{kPa}$, while Table (5) illustrates the values at stress of $100 \mathrm{kPa}$.

Table 4: $\mathrm{C}_{\mathrm{v}}$ and $\mathrm{k}$ for uncontaminated and contaminated soil at stress 25 $\mathrm{kPa}$.

\begin{tabular}{|c|c|c|c|c|}
\hline Coefficient & CL0 & CL5 & CL10 & CL15 \\
\hline $\mathrm{C}_{\mathrm{v}}\left(\mathrm{cm}^{2} / \mathrm{sec}\right) \times 10^{-3}$ & 0.883 & 1.77 & 3.53 & 3.82 \\
\hline $\mathrm{k}(\mathrm{cm} / \mathrm{sec}) \times 10^{-7}$ & 0.443 & 0.942 & 2.223 & 2.443 \\
\hline
\end{tabular}

The reason of the increasing of the permeability is belong to the shrinkage of the double layer encirclement the particle of clay. The shrinkage is proceeding by the reducedinsulation constant of oil comparing with water. When the soil shrank, the cracks are developed which lead to an increase of the coefficient of permeability.

Table 5: $\mathrm{C}_{\mathrm{v}}$ and $\mathrm{k}$ for uncontaminated and contaminated soil at stress 100 $\mathrm{kPa}$.

\begin{tabular}{|c|c|c|c|c|}
\hline Coefficient & CL0 & CL5 & CL10 & CL15 \\
\hline $\mathrm{C}_{\mathrm{v}}\left(\mathrm{cm}^{2} / \mathrm{sec}\right) \times 10^{-3}$ & 0.883 & 0.49 & 0.34 & 0.33 \\
\hline $\mathrm{k}(\mathrm{cm} / \mathrm{sec}) \times 10^{-7}$ & 0.443 & 0.261 & 0.214 & 0.216 \\
\hline
\end{tabular}

As illustrated in Table (5), the coefficient of consolidation decreases with increasing of crude oil which results in a decrease in the permeability. Decrease in permeability may be due to reduction in pore volume of soil. Because of lower permeability, the time required for consolidation increased and hence the coefficient of consolidation decreased as $\left(\mathrm{C}_{\mathrm{v}}\right)$ is directly proportional to the hydraulic conductivity of soil(Mitchell, 1976).

This is in line with the findings of Ayininuola and Kwashima (2015). Also Khamehchiyan et al. (2007) obtained similar result in their study of the effect of "crude oil"on the properties of coastal soils. This reduction in permeability hinders the flow of water in the soil which invariably affects the groundwater levels.

From the previous results, it can be concluded that the settlement of the soil may increase with increasing crude oil because of increasing of compression index and coefficient of consolidationwhereas the settlement of the soil depends on these parameters.

\subsubsection{Uniaxial (unconfined) compression strength tests (UCS):}

To investigate the strength properties of uncontaminated and crude oil contaminated clayey soil, "unconfined compressive strength tests" were made and all the tests were done on specimens prepared at "optimum moisture content (O.M.C.) and "maximum dry unit weight". Furthermore, unconfined compression tests were also conducted onsamples contaminated with 5,10 and $15 \%$ of crude oil content. Figure 14 shows the results of UCS test.

According to the values of unconfined compression test, there is a decrease in the correlation between $\mathrm{q}_{\mathrm{u}}$ and crude oil content except for $5 \%$ crude oil content that shows an increase in $\mathrm{q}_{\mathrm{u}}$ as shown in Figures 14 and 15. Based on the relationship of consistency and compressive strength of clays, the specimens change from very stiff consistency for specimens contaminated with 5\% crude oil to soft consistency at the crude content of $15 \%$ crude oil with the guidelines presented by Das (1994).

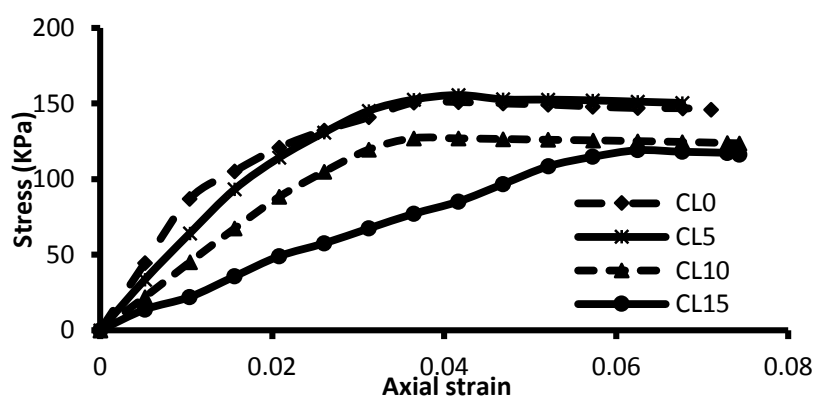

Fig. 14: Unconfined compressive strength curve of the clean and contaminated clayey samples (at normal stress $100 \mathrm{kPa}$ ).

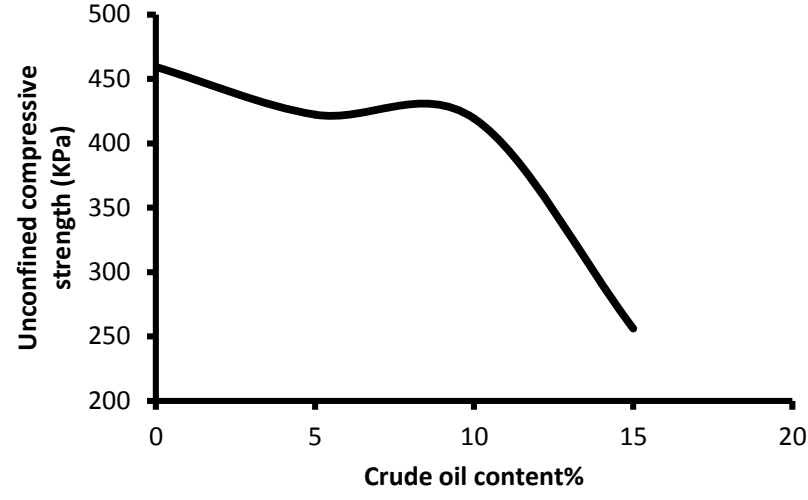

Fig. 15: Effect of crude oil on shear strength.

\section{Conclusions}

The following conclusions can be found from this study:

1. The gradation of soil particles was affected by contamination with crude oil, so it becomes coarser than the uncontaminated soil.

2. The specific gravity decreased by $13 \%$ approximately with increasing crude oil content to percent of $15 \%$ by weight of dry soil sample.

3. Addition of crude oil to clayey soil caused $40 \%$ increase in the liquid limit, 27\% increase in the plastic limit and $53 \%$ increase in the plasticity index as crude oil content increased $15 \%$ by weight of dry soil and that is considered as an indicator that the contaminated soil with crude oil becomes less workable.

4. The maximum dry density is reduced slightly; $5 \%$ with increasing of "crude oil" content to $15 \%$ in the clayey soil, while the optimum water content reduced significantly $33 \%$ approximately with the same increasing of crude oil.

5. With increasing of crude oil content of the contaminated soil, the compression index increased. While the coefficient of consolidation $\left(\mathrm{C}_{\mathrm{v}}\right)$ of contaminated soil has infrequent values.

6. The shear strength of the soil was affected by crude oil. The unconfined compressive strength shows an earlier increasing and then a significant reduction was noted with the increasing of crude oil more than $5 \%$.

\section{References}

[1] Abosede, E.E. (2013), "Effect of Crude Oil Pollution on some Soil Physical Properties", Journal of Agriculture and Veterinary Science, 6(3),14-17.

[2] Abousnina R. M., Manalo A., Shiau J. \&Lokuge W., (2015): "Effects of Light Crude Oil Contamination on the Physical and Mechanical Properties of Fine Sand", Soil and Sediment Contamination: An International Journal, DOI: 10.1080/15320383.2015.1058338

[3] Alrubaye, A. J., Hasan, M., Fattah, M. Y., (2016), "Improving Geotechnical Characteristics of Kaolin Soil Using Silica Fume and Lime", Special Topics \& Reviews in Porous Media- An International Journal, Vol. 7 (1), pp. 77-85.

[4] Ali, H. A. R., (1999), "Some Geotechnical Properties of Oil Contaminated Soil", M.Sc. thesis, College of Engineering, University of Baghdad.

[5] ASTM (American Society for Testing and Materials), (2006) "Annual book of ASTM standards" section 4, Construction Soil and Rock, Vol. 4.08. ASTM, Philadelphia, PA.

[6] Ayininuola G.M., Kwashima O.F, (2015), "Effect of Diesel Oil Contamination on Soil NaturalRecharge of Groundwater", 2nd International Conference on Geological and Civil Engineering. DOI: 10.7763/IPC BEE. 2015.V80.9.

[7] Das, B.M., (1994), "Principles of Geotechnical Engineering", 3rd edition, Boston, MA: PWS, Puldishing Company, 436 pp. 
[8] Fine, P., Graber, E.R., and Yaron, B., (1997), "Soil Interactions with Petroleum Hydrocarbons", abiotic Process, Soil Technology 10, 133-153.

[9] Ismaeel, N. F., Mollah M. A., (1998), "Leaching Effect on Properties of cemented sand in Kuwait", Journal of Geotechnical and Geoenvironmental Engineering, ASCE, 124(10), 997-1004.

[10] Karkush M. O, and Abdul Kareem Z., (2017), "Investigation the Impacts of Fuel Oil on the Geotechnical Properties of Cohesive Soil", Engineering Journal, University of Baghdad, Vol. 21, No. 4, 127-137.

[11] Kermani M. and Ebadi T. (2012) "The Effect of Oil Contamination on the Geotechnical Properties of Fine-Grained Soils", Soil and Sediment Contamination: An International Journal, 21:5, 655-671, DOI: $10.1080 / 15320383.2012 .672486$

[12] Khamehchiyan, M., Charkhabi, A. H. and Tajik, M., (2007), "Effect of Crude Oil on Geotechnical Properties of Clayey and Sandy Soils", Eng. Geotech. Div., 89, 220-229.

[13] Meegoda, N.J. and Ratnaweera, P., (1994), "Compressibility of Contaminated FineGrained Soils", Geotechical Testing Journal, ASTM, 17(1), 101-112.

[14] Mitchell, J.K., (1976), "Fundamentals of Soil Behaviour", John Wiley, New York.

[15] Ur-Rahman, H., Abduljauwad, S. N. and Akram, T. (2007), "Geotechnical Behavior of Oil- Contaminated Fine- Grained Soils", Electronic Journal of Geotechnical Engineering, 12A, 15-23. 